\title{
Seasonal fluxes of phosphate and ammonium across the sediment-water interface in a shallow small estuary (Palmones River, southern Spain)
}

\author{
V. Clavero ${ }^{1, *}$, J. J. Izquierdo ${ }^{1}$, J. A. Fernández ${ }^{2}$, F. X. Niell ${ }^{1}$ \\ ${ }^{1}$ Department of Ecology, and ${ }^{2}$ Department of Plant Biology, Faculty of Sciences, University of Málaga, \\ Campus de Teatinos s/n, 29071 Málaga, Spain
}

\begin{abstract}
Seasonal variations in oxygen, phosphate and ammonium fluxes between the sediment and overlying water were measured in a small shallow estuary (Palmones River Estuary, southern Spain) from July 1996 to July 1997. Fluxes at the sediment-water interface were measured in situ and compared with those obtained from the pore water gradients. Oxygen consumption rates ranged from 62.5 to $87.4 \mathrm{mmol} \mathrm{m}^{-2} \mathrm{~d}^{-1}$, and were highly correlated with phosphate (226 to $1597 \mu \mathrm{mol} \mathrm{m}^{-2} \mathrm{~d}^{-1}$ ) and

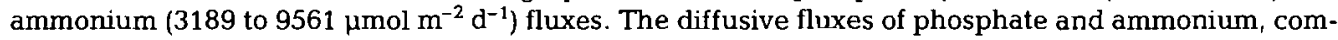
puted from the pore water gradient, were lower than those measured in situ (from 7 to 24 times for phosphate and from 21 to 55 times for ammonium). Nutrient fluxes are well correlated with temperature and with the C:N ratio of organic matter within the upper $2 \mathrm{~cm}$ of the sediment.
\end{abstract}

KEY WORDS: Phosphate and ammonium fluxes - Sediment - Oxygen · Consumption - Organic matter Palmones Estuary

\section{INTRODUCTION}

The biogeochemical transformations occurring in sediments cause chemical mass transfers from sediments to the water column. Nutrient release from sediments can be an important factor in controlling the trophic state of aquatic systems, especially in shallow waters (Nixon et al. 1976, Boynton et al. 1980, Hopkinson \& Wetzel 1982, Ingall \& Jahnke 1997).

When organic matter is accumulated due to high productivity, the sediment may act as a sink of phosphorus and nitrogen. The total decomposition of organic matter returns carbon, nitrogen and phosphorus to their soluble forms. In anaerobic sediments, bacteria reduce nitrate to ammonium and $\mathrm{N}_{2 i}$ phosphorus remains soluble because it does not form insoluble compounds with metals under these conditions (Libe 1992). Thus, ammonium and phosphate could be released from the sediments to overlying water, en-

*E-mail: vic@uma.es hancing primary production in an amplified positive feedback (Klump \& Martens 1981, Blackburn \& Henriksen 1983, Furrer et al. 1996, van Cappellen \& Gaillard 1996).

To determine the quantity of nutrients buried versus that recycled to overlying water, benthic nutrient fluxes together with measurements of oxygen consumption could provide valuable information on the rate of organic matter mineralization in sediments (Aller 1980, Elderfield et al. 1981, Smith et al. 1983, Hammond et al. 1985). Additionally, nutrient fluxes can be computed from pore water profiles according to Fick's diffusion law (McCaffrey et al. 1980, Callender \& Hammond 1982, Balzer et al. 1983, Clavero et al. 1991). Comparison of computed fluxes with in situ flux measurements can provide information about the relation between fluxes at the sediment-water interface and nutrient cycling within the sediment column.

Palmones is a small shallow estuary located near the Strait of Gibraltar (southern Spain). Recent climatic changes, characterized by a severe drought, have decreased river discharge dramatically, increasing the 
influence of tides on the water flow in the estuarine basin (Carreira et al. 1995, Clavero et al. 1997a, 1999). Important changes in the estuarine biota have recently been described (Izquierdo 1996, Clavero et al. 1997a, Avilés 1998). For example, until 1992 Nereis diversicolor comprised the entire animal biomass in sediments (Clavero et al. 1991, 1992), but this species has not been observed since. Furthermore, the seagrass Zostera noltii, which covered $10 \%$ of the sediment surface (Pérez-Llorens \& Niell 1990, Hérnandez et al. 1994), has disappeared and the seaweed Ulva rotundata is now the dominant species, covering up to $90 \%$ of the sediment surface (Hérnandez et al. 1997) in some areas of the estuary. These $U$. rotundata mats interpose a barrier for oxygen diffusion between the sediment and water or air and may have a local impact on biogeochemical $\mathrm{P}$ and $\mathrm{N}$ fluxes.

The aim of the present study was to describe the seasonal variation of phosphate, ammonium and oxygen fluxes between the sediment and overlying water, using in situ measurements and pore water nutrient concentration data. Nutrient fluxes are related to sediment characteristics in order to estimate the fraction of nutrients buried versus the fraction of phosphate and ammonium released into the overlying water. Oxygen fluxes are used to provide information on the variables influencing nutrient exchange.

\section{MATERIALS AND METHODS}

Study area. The Palmones River Estuary is located in Algeciras Bay (Fig. 1), southern Spain, at the end of a small catchment area $\left(97 \mathrm{~km}^{2}\right)$. It is a small, shallow, partially mixed estuary (mean depth $<1.5 \mathrm{~m}$ ). Tidal movements have a maximum amplitude of $2 \mathrm{~m}$, and extensive areas of mud emerge daily at low tide (Clavero et al. 1997a). Additional details about the estuary can be found in Carreira et al. (1995) and Niell et al. (1996).

The site chosen for the present study is located in the middle of the estuary (Fig. 1), where sediment and water characteristics have been documented since 1987 (Pérez-Llorens \& Niell 1990, Clavero et al. 1991. 1992, 1997a, Hernández et al. 1994, 1997).

In situ flux measurements. Benthic flux experiments were conducted bimonthly from July 1996 to July 1997. Net fluxes of dissolved phosphate, ammonium and dissolved oxygen between the sediment and overlying water were measured using 3 opaque PVC chambers (volume $30 \mathrm{l}$, section $0.2 \mathrm{~m}^{2}$ ) at low tide. Water samples $\left(10 \mathrm{ml}\right.$ each for $\mathrm{PO}_{4}{ }^{3-}$ and $\left.\mathrm{NH}_{4}{ }^{+}\right)$were collected at $20 \mathrm{~min}$ intervals for $4 \mathrm{~h}$. At the same time, dissolved oxygen was measured using a multisonde MultiLine P3 pH/Oxi WTW. Water samples were carefully with- drawn from the chambers, avoiding the generation of turbidity using syringes fitted with Whatman GF/C filters. Immediately after collection, samples were frozen and transferred to the laboratory for later analysis.

Net dissolved oxygen, phosphate and ammonium fluxes $\left(J_{0}\right)$ across the sediment-water interface were calculated according to Aller et al. (1985):

$$
J_{0}=M A^{-1} T^{-1} \quad \text { where } \quad M=\Sigma V_{t}\left(C_{t}-C_{t-1}\right)
$$

$J_{0}$ is the oxygen, phosphate or ammonium flux ( $\mu \mathrm{mol}$ $\left.\mathrm{m}^{-2} \mathrm{~d}^{-1}\right), V_{t}$ is the total volume of overlying water at time $t$ in the chamber (in litres), $C_{t}$ and $C_{t-1}$ are the dissolved oxygen, phosphate or ammonium concentrations at times $t$ and $t-1$, respectively, in the water $\left(\mu \mathrm{mol} \mathrm{l} \mathrm{l}^{-1}\right.$ ) and $A$ is the surface of the sediment enclosed by the flux chamber $\left(\mathrm{m}^{2}\right)$.

Flux estimate and sediment characterization. Two PVC cores $(20 \mathrm{~cm}$ internal diameter, $20 \mathrm{~cm}$ long) inserted into the sediment adjacent to the PVC flux chamber were retrieved and transported to the laboratory in an ice-box at $4^{\circ} \mathrm{C}$. In the laboratory the sediment was extruded from the core and sliced into $2 \mathrm{~cm}$ segments under $\mathrm{N}_{2}$ atmosphere. Each slice was weighed and divided into 2 subsamples. The first subsample was centrifuged under $\mathrm{N}_{2}$ atmosphere to extract the pore water $\left(3000 \mathrm{rpm}[1000 \times g], 15 \mathrm{~min}, 4^{\circ} \mathrm{C}\right)$ which then passed through Whatman GF/C filters. The other sediment subsample was used to determine

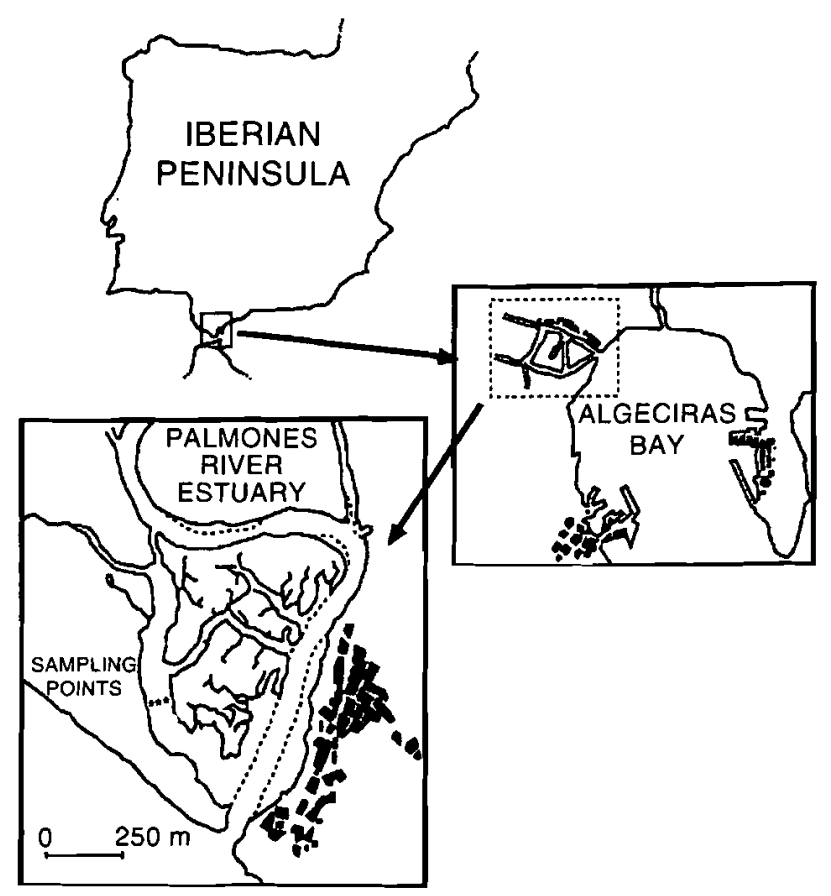

Fig. 1. Map of the Palmones River Estuary showing location of sampling station 
porosity, wet and dry mass, organic matter, organic carbon, and total nitrogen and phosphorus contents.

Calculated diffusive fluxes. Diffusive fluxes $\left(J_{\mathrm{d}}\right)$ were computed from concentration gradients according to Berner (1980):

$$
J_{\mathrm{d}}=\phi_{0} D_{\mathrm{s}}(\partial C / \partial \mathrm{x})
$$

$J_{\mathrm{d}}$ is the diffusive flux ( $\left.\mu \mathrm{mol} \mathrm{m} \mathrm{m}^{-2} \mathrm{~d}^{-1}\right), \phi_{0}$ is the porosity in the upper part $(2 \mathrm{~cm})$ of the sediment, $\partial C / \partial x$ is the concentration gradient of dissolved phosphate or ammonium in the interstitial water $\left(\mu \mathrm{mol} \mathrm{l} \mathrm{l}^{-1} \mathrm{~cm}^{-1}\right)$, and $D_{\mathrm{s}}$ is the whole sediment diffusion coefficient $\left(\mathrm{cm}^{2} \mathrm{~s}^{-1}\right)$ expressed by Krom \& Berner (1980) as:

$$
D_{\mathrm{s}}=D_{0} / \phi_{0} F^{\prime}
$$

where $D_{0}$ is the diffusion coefficient in water at infinite dilution (Li \& Gregory 1974) and $F^{\prime}$ is the modified formation factor from Archie's relation $\left(F=\phi^{-2}\right.$, Manheim 1970). $D_{0}$ values for phosphate $\left(7 \times 10^{-6} \mathrm{~cm}^{2} \mathrm{~s}^{-1}\right)$ and ammonium $\left(17.6 \times 10^{-6} \mathrm{~cm}^{2} \mathrm{~s}^{-1}\right)$ were taken from Li \& Gregory (1974).

Open water column characterization. In triplicate, salinity, temperature and dissolved oxygen were measured using a multisonde YSI Gran 3800 water quality logger. Water samples were taken with a Van Dorn bottle according to experiment intervals (at the same state of tide) and passed through Whatman GF/C filters for phosphate and ammonium analysis.

Analytical methods. Water samples from the water column, flux experiments and interstitial water were analyzed for ammonium (Slawyk \& MacIsaac 1972) and phosphate (Fernández et al. 1985) using a Technicon Autoanalyzer AAII. Sediment water content was determined by drying at $60^{\circ} \mathrm{C}$. Organic matter content of dried samples was determined from weight loss following $4 \mathrm{~h}$ ashing at $450^{\circ} \mathrm{C}$, in order to avoid losses by unstable $\mathrm{CaCO}_{3}$. Organic carbon and total nitrogen were determined with a CHN Carlo Erba (Model 1106), total phosphorus was measured according to methods outlined in Sommers \& Nelson (1972).

\section{RESULTS}

\section{Open water column}

Temperature followed a seasonal pattern, and ranged from $14^{\circ} \mathrm{C}$ (January 1997 ) to $20.5^{\circ} \mathrm{C}$ (July 1996). Salinity ranged from 31 to 36 ; the lower values coincided with the rainy period (from January to March 1997) in the catchment area (Fig. 2a). Ammonium and phosphate concentrations (Fig. 2b) were fairly constant from July to November 1996 (2.5 to $3 \mu \mathrm{mol} \mathrm{l} \mathrm{l}^{-1}$ for phos- phate and 19 to $26 \mu \mathrm{mol} \mathrm{l}^{-1}$ for ammonium), decreased to a minimum in January (1.4 and $8.2 \mu \mathrm{mol} \mathrm{l}^{-1}$ for phosphate and ammonium, respectively), increased in March and May (up to $8 \mu \mathrm{mol}^{-1}$ for phosphate and $89 \mu \mathrm{mol} \mathrm{l}^{-1}$ for ammonium), and decreased again in July $1997\left(1.4 \mu \mathrm{mol} \mathrm{l^{-1 }}\right.$ phosphate and $43 \mu \mathrm{mol} \mathrm{l^{-1 }}$ ammonium). The ratio of ammonium to phosphate ranged from 6 (January 1996) to 29 (July 1997). Dissolved oxygen (Fig. $2 \mathrm{c}$ ) varied from 6.5 to $8.5 \mathrm{mg} \mathrm{l}^{-1}$ ( 60 to $100 \%$ saturation), with the lowest concentration occurring in the rainy period (March 1997). The 1-way
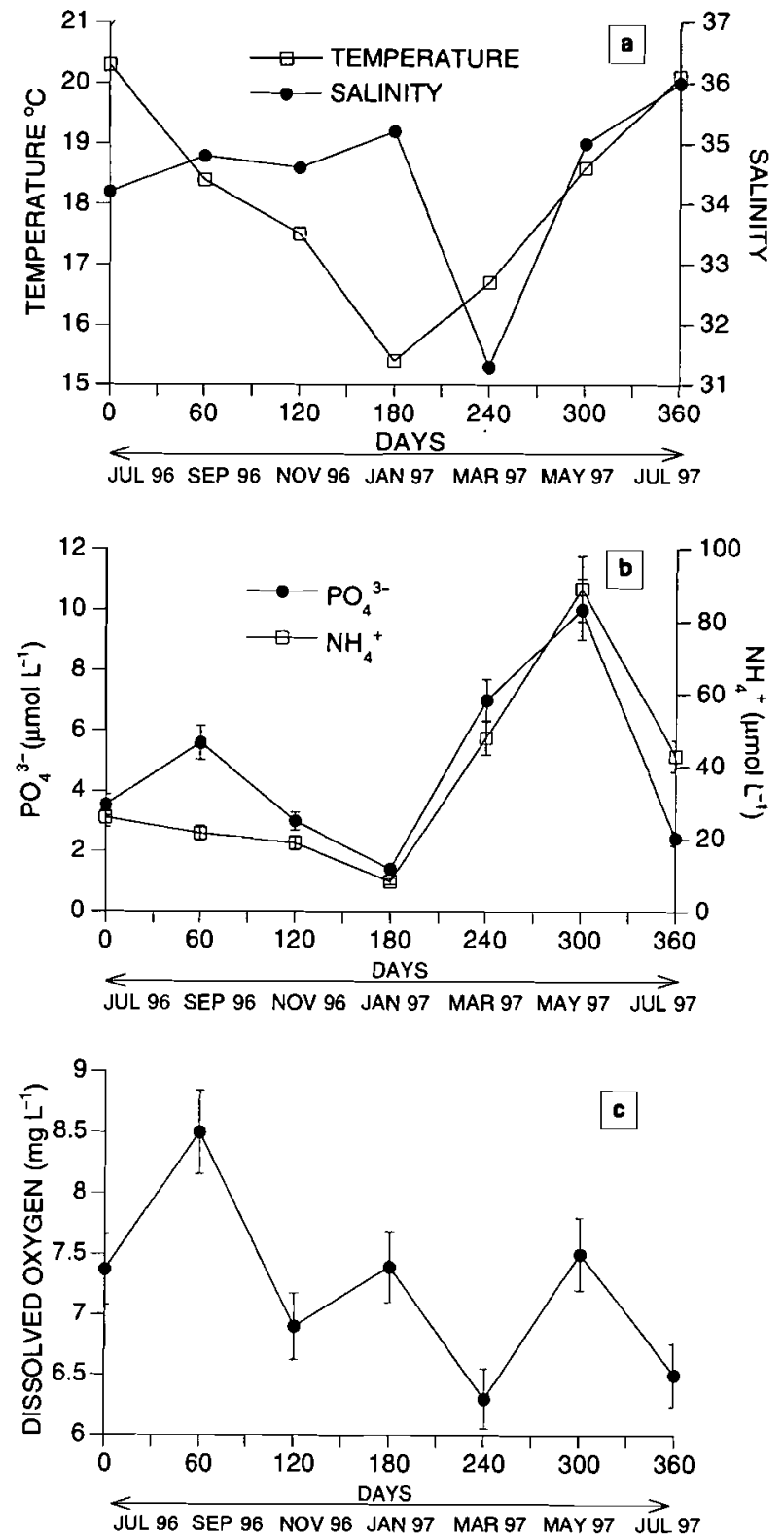

Fig. 2. Seasonal variations in the open water column of (a) temperature and salinity, (b) dissolved phosphate and ammonium and (c) dissolved oxygen 
ANOVA indicates significant differences $(\alpha=0.001)$ between the sampling occasions. The post hoc test (Tukey-Kramer, $(\alpha=0.001)$ shows differences between all the mean values compared.

Sediment characterization. Vertical gradients were observed in sediment profiles of organic matter, organic carbon, total nitrogen and phosphorus (Fig. 3), with maximum values for organic matter, organic carbon and nitrogen at $4 \mathrm{~cm}$ depth. In contrast, the maximum values for phosphorus were observed at $10 \mathrm{~cm}$. Depth-integrated organic carbon ranged from $1.1 \%$ (November 1996 ) to $2.75 \%$ of dry mass in July 1996 (Table 1). Total nitrogen was $0.21 \%$ of dry mass, with maximum values in May. Sedimentary phosphorus is highly negatively correlated with the rainy season $(r=-0.93)$, decreasing in concentration from $0.15 \%$ in July 1996 to $0.01 \%$ of dry mass in March 1997. Organic matter ranged from $6.2 \%$ (January 1997 ) to $9.4 \%$ (July 1997).

Phosphate and ammonium in pore water. Pore water phosphate and ammonium concentrations were highly variable over depth and time (Fig. 4). The highest phosphate $\left(380 \mu \mathrm{mol} \mathrm{l}^{-1}\right)$ and ammonium ( $3500 \mathrm{\mu mol} \mathrm{l}^{-1}$ ) concentrations were detected in July 1997. The minimum values were found in November $1996\left(<100 \mu \mathrm{mol} \mathrm{l}^{-1}\right.$ of phosphate and $<600 \mu \mathrm{mol} \mathrm{l}^{-1}$ of ammonium). Over the study period phosphate and ammonium concentrations in pore water were higher
Table 1. Depth integrated values of porosity $(\phi, \%)$, organic matter $(\mathrm{OM}, \%)$, carbon $(\mathrm{C})$, nitrogen $(\mathrm{N})$ and phosphorus $(\mathrm{P})$

( $\%$ of dry mass) in the sediment over the study period

\begin{tabular}{|llllll|}
\hline & $\phi$ & OM & C & N & P \\
\hline Ju1 1996 & 0.82 & 9.0 & 2.75 & 0.17 & 0.15 \\
Sep 1996 & 0.85 & 8.2 & 2.10 & 0.13 & 0.14 \\
Nov 1996 & 0.86 & 6.3 & 1.10 & 0.21 & 0.11 \\
Jan 1997 & 0.86 & 6.2 & 1.35 & 0.20 & 0.06 \\
Mar 1997 & 0.84 & 8.6 & 1.74 & 0.18 & 0.01 \\
May 1997 & 0.85 & 8.2 & 2.40 & 0.22 & 0.05 \\
Jul 1997 & 0.84 & 9.4 & 1.62 & 0.19 & 0.06 \\
\hline
\end{tabular}

than those observed in the overlying water, from 18 to 210 times for phosphate and from 17 to 166 times for ammonium.

\section{In situ flux measurements}

Benthic oxygen, phosphate and ammonium fluxes $\left(J_{0}\right)$, calculated using Eq. (1) using benthic flux chamber data, are given in Tables $2 \& 3$. These fluxes follow a marked seasonal evolution with maximum values in the summer period $\left(87.4 \mathrm{mmol} \mathrm{m}^{-2} \mathrm{~d}^{-1}\right.$ for oxygen, $1597 \mu \mathrm{mol} \mathrm{m}^{-2} \mathrm{~d}^{-1}$ for phosphate and $9581 \mu \mathrm{mol} \mathrm{m}{ }^{-2} \mathrm{~d}^{-1}$ for ammonium) and a minimum in the rainy period in January $\left(62.5 \mathrm{mmol} \mathrm{m}^{-2}\right.$
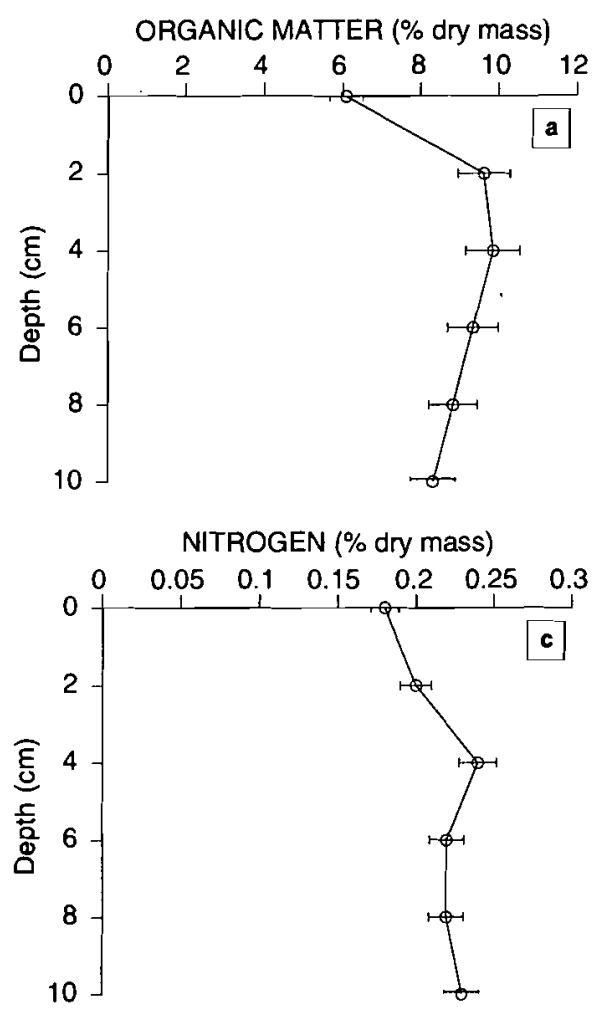

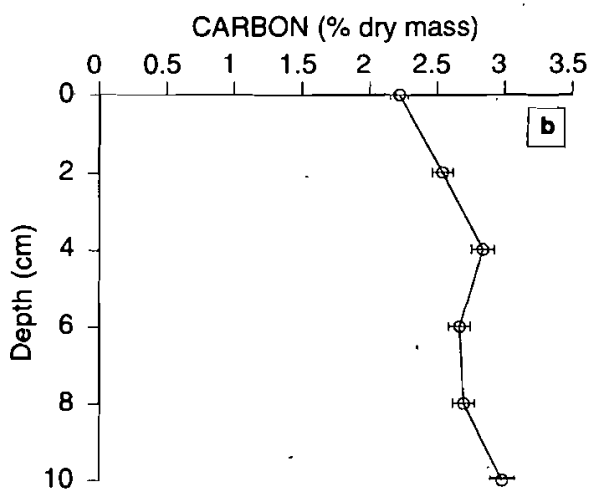

PHOSPHORUS $\times 10^{2}$. (\% dry mass)

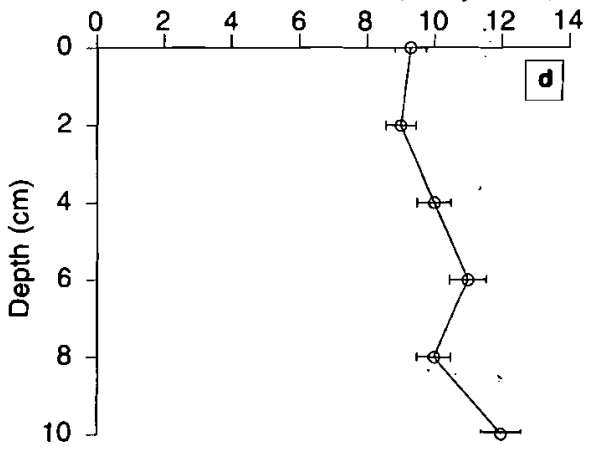

Fig. 3. Mean ( \pm standard deviations) annual sediment profiles of (a) organic matter, (b) organic carbon, (c) total nitrogen and (d) total phosphorus within the upper $10 \mathrm{~cm}$ 


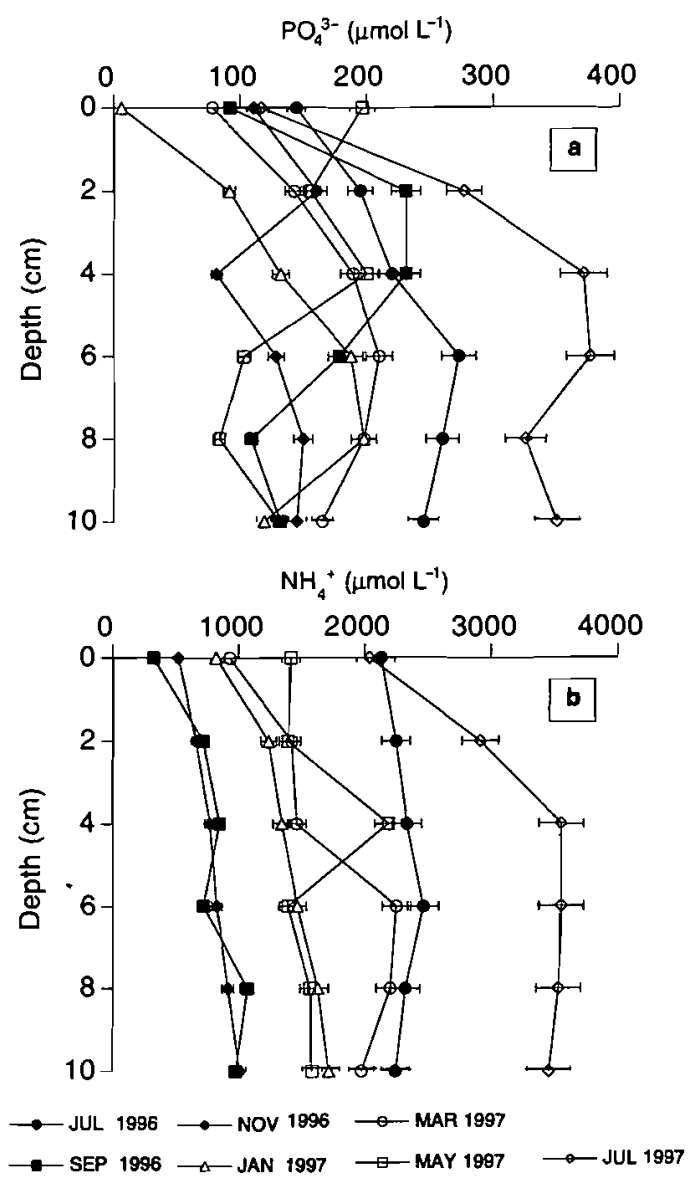

Fig. 4. Seasonal pattern of pore water (a) phosphate and (b) ammonium profiles within the upper $10 \mathrm{~cm}$

$\mathrm{d}^{-1}$ for oxygen, $266 \mu \mathrm{mol} \mathrm{m} \mathrm{m}^{-2} \mathrm{~d}^{-1}$ for phosphate and $3189 \mathrm{mmol} \mathrm{m}^{-2} \mathrm{~d}^{-1}$ for ammonium). Significant differences (ANOVA, $\alpha=0.001$ ) between the sampling occasions were found, and the Tukey-Kramer test showed differences between all the mean values compared.

\section{Calculated diffusive fluxes}

Phosphate and ammonium benthic fluxes calculated from pore water gradients using Eq. (2) $\left(J_{\mathrm{d}}\right)$ ranged from 30 to $67 \mu \mathrm{mol} \mathrm{m} \mathrm{m}^{-2} \mathrm{~d}^{-1}$ for phosphate, which is lower than in situ fluxes (Table 2). Likewise, the ammonium fluxes calculated from pore water gradients with values from 114 to $174 \mu \mathrm{mol} \mathrm{m} \mathrm{m}^{-2} \mathrm{~d}^{-1}$ were lower than in situ fluxes (Table 2).

\section{DISCUSSION}

Increase and enhancement of phosphate and ammonium fluxes were observed in this study according to sediment composition, seasonal variability and historic changes.

(1) In the replicate benthic flux chambers used, the fluxes of oxygen, phosphate and ammonium had low coefficients of variation, with values of $6.24,10.66$ and $7.25 \%$, respectively (Tables $2 \& 3$ ). This homogeneity is a recent phenomenon; prior to 1993 the coefficients of variation obtained were $30 \%$ (Clavero et al. 1991 , 1992), possibly attributable to the presence of Nereis diversicolor which dominated the benthic fauna. The disappearance of macrofauna may have reduced the variability of fluxes. In the absence of bioturbation (Carreira et al. 1995, Estacio et al. 1999), a possible explanation for the flux enhancements could be that mineralization of nutrients occurs primarily at the sediment-water interface rather than throughout the sediment column. Since oxygen typically only penetrates a few millimetres depth into clay sediments (Revsbech et al. 1983, Plante et al. 1989, Witt et al. 1989), decomposition of organic matter takes place mainly at the surface. Taking into account the high organic matter content $(8 \pm 1.2 \%$ dry mass) of the sediment (Table 1), the mineralization process could be

Table 2. Monthly averaged values (mean \pm standard deviation) and coefficient of variation (CV) of in situ ( $\left.J_{0}\right)$ and calculated diffusive $\left(J_{\mathrm{d}}\right)$ fluxes $\left(\mu \mathrm{mol} \mathrm{m} \mathrm{m}^{-2} \mathrm{~d}^{-1}\right)$ from pore water gradients for phosphate and ammonium, $J_{0}: J_{\mathrm{d}}$ is the ratio between in situ and calculated diffusive fluxes

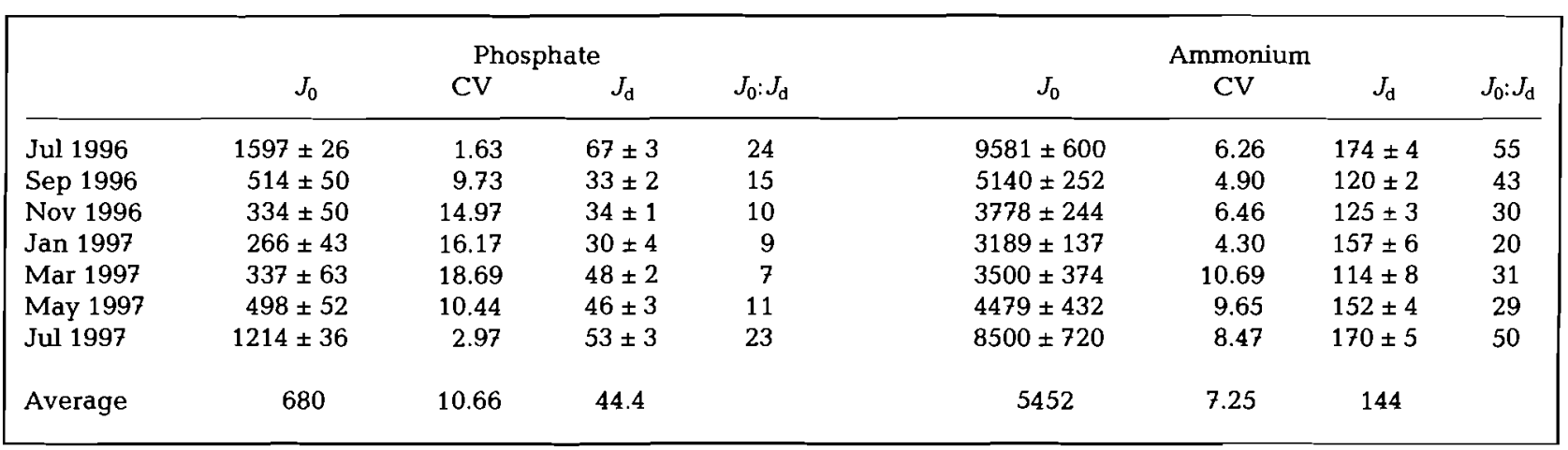


Table 3. Monthly averaged values (mean \pm SD) and coefficient of variation (CV) of sediment oxygen consumption $\left(\mathrm{mmol} \mathrm{m}{ }^{-2} \mathrm{~d}^{-1}\right) . \mathrm{NH}_{4}{ }^{4}: \mathrm{PO}_{4}{ }^{3-}$ is the ratio between in situ fluxes of ammonium and phosphate, and $\mathrm{O}: \mathrm{NH}_{4}{ }^{+}$is the ratio between oxygen consumption and in situ fluxes of ammonium

\begin{tabular}{|lcrcc|}
\hline & \multicolumn{1}{c}{$\mathrm{O}_{2}$} & \multicolumn{1}{c|}{$\mathrm{CV}$} & $\mathrm{NH}_{4}{ }^{+}: \mathrm{PO}_{4}{ }^{3-}$ & $\mathrm{O}^{2} \mathrm{NH}_{4}{ }^{+}$ \\
\hline Jul 1996 & $87.4 \pm 4$ & 1.63 & 6 & 9 \\
Sep 1996 & $67.4 \pm 5$ & 9.73 & 10 & 13 \\
Nov 1996 & $64.2 \pm 3$ & 14.97 & 11 & 17 \\
Jan 1997 & $62.5 \pm 5$ & 16.17 & 12 & 19 \\
Mar 1997 & $65.8 \pm 3$ & 18.69 & 10 & 19 \\
May 1997 & $72.6 \pm 8$ & 10.44 & 10 & 16 \\
Jul 1997 & $86.6 \pm 3$ & 2.97 & 7 & 10 \\
Yearly average & 10.66 & 9.43 & 14.71 \\
Summer average & & 6.5 & 9.5 \\
\hline
\end{tabular}

very rapid. The quality of organic matter that becomes incorporated in the sediments is an important characteristic of a benthic system (Soetaert et al. 1998) because of its presumed impact on the magnitude and timing of various benthic fluxes (Martin \& Bender 1988; Soetaert et al. 1996).

(2) Seasonal variations in phosphate and ammonium fluxes are evident (1-way ANOVA, $\alpha=0.001$ and Tukey-Kramer test); maximum fluxes occur in summer (July 1996 and 1997), when the mineralization of sedimentary organic matter is typically most rapid. This pattern is frequently observed (Aller 1980, Aller \& Benninger 1981, Seitzinger 1987, Clavero et al. 1991, Forja et al. 1994) and is related to the dependence of benthic fluxes on temperature (Boynton et al. 1980, Fisher et al. 1982, Kelderman 1984). Our data show a strong correlation between fluxes and temperature over the studied period (Fig. 5, r = 0.88 for oxygen, $\mathbf{r}=0.95$ for phosphate and $\mathbf{r}=0.95$ for ammonium $i$ $\alpha=0.001$ ). Seasonality in benthic nutrient fluxes in the estuary could be accounted for by the effect of temperature on both diffusion and metabolic activity of benthic organisms. Bulk flow of interstitial water due to seasonal water gradients (Fisher et al. 1982, Carreira et al. 1995, Izquierdo 1996) could also explain the observed changes in nutrient fluxes. Many authors have suggested that high rates of sulfate reduction may occur in the summer (Jørgensen \& Sørensen 1985, Klump \& Martens 1987), and may lead to an enhancement in nitrogen and phosphorus release by the sediments (Clavero et al. 1997b).

(3) The ratio in situ to calculated diffusive fluxes is defined as the flux enhancement (i.e. Callender \& Hammond 1982). The values of calculated diffusive fluxes for phosphate and ammonium, calculated from pore water gradients, are also included in Table 2. These fluxes ranged from 30 to $67 \mu \mathrm{mol} \mathrm{m} \mathrm{m}^{-2} \mathrm{~d}^{-1}$ for
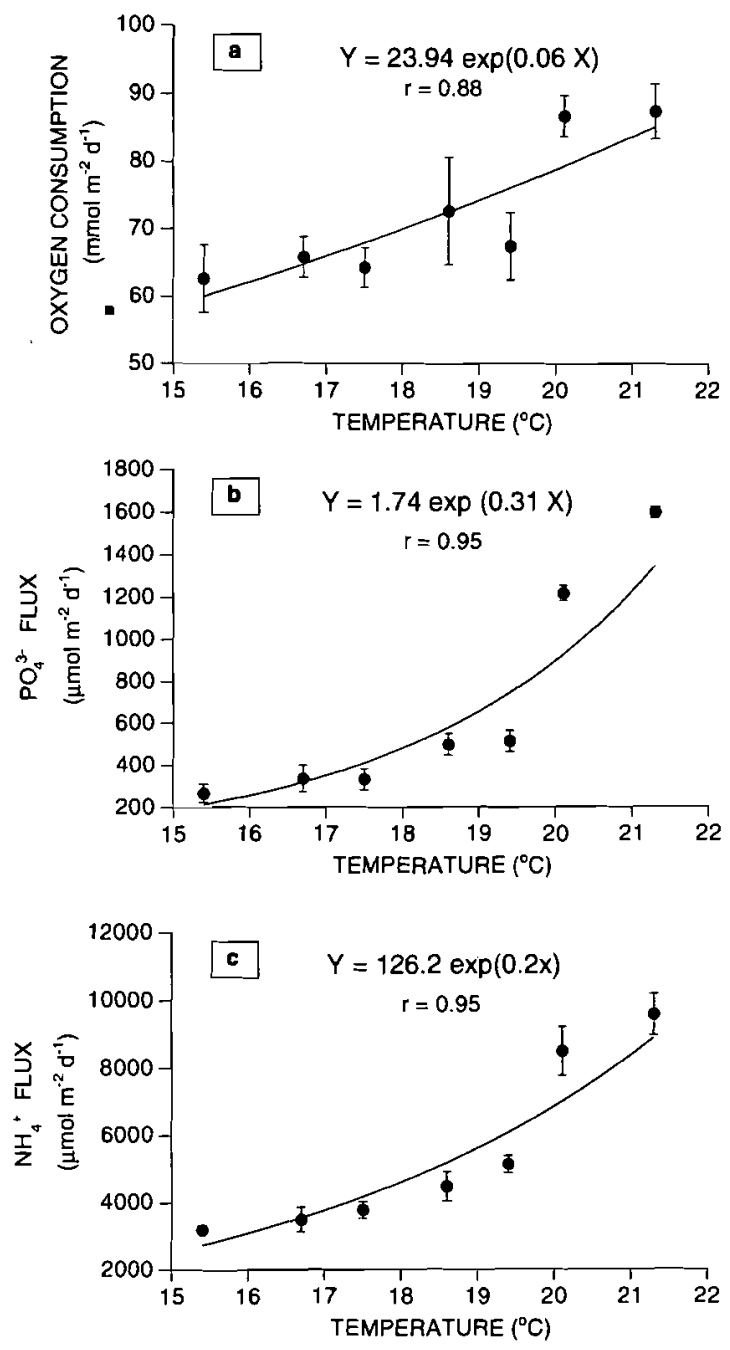

Fig. 5. Variation (mean \pm standard deviations) of (a) oxygen consumption, (b) phosphate and (c) ammonium benthic fluxes with temperature, from in situ benthic flux chambers

phosphate and between 114 and $174 \mu \mathrm{mol} \mathrm{m} \mathrm{m}^{-2} \mathrm{~d}^{-1}$ for ammonium. The values for oxygen consumption, phosphate and ammonium fluxes are of the same order of magnitude as those obtained in similar studies (Table 4), but a comparison of our fluxes with the area closest to our site (Forja et al. 1994) show our data to be lower. The flux enhancement ranged from 7 to 24 for phosphate and from 20 to 55 for ammonium (Table 2). On average, calculated diffusive fluxes account for $<10 \%$ of in situ fluxes. The general interpretation is an organic matter degradation which, in turn, produces pore water nutrients which generate diffusive fluxes, but a relationship between fluxes measured in situ and organic matter degradation is also possible. Oxygen fluxes are significantly correlated ( $r=0.90$ ) with the organic carbon in the upper $2 \mathrm{~cm}$ of the sediment (Fig. 6a). This result has been 
Table 4. Oxygen uptake ( $\mathrm{mmol} \mathrm{m} \mathrm{m}^{-2} \mathrm{~d}^{-1}$ ) and benthic nutrient exchanges rates ( $\mu \mathrm{mol} \mathrm{m} \mathrm{m}^{-2} \mathrm{~d}^{-1}$ ) from some estuarine and marine ecosystems

\begin{tabular}{|lcccl|}
\hline Site & $\mathrm{O}_{2}$ & $\mathrm{NH}_{4}{ }^{+}$ & $\mathrm{PO}_{4}{ }^{3-}$ & Source \\
\hline South River (NC, USA) & $19.8-75.6$ & $0-6408$ & $(-200)-547$ & Fisher et al. (1982) \\
Neuse River (NC, USA) & $19.6-51.8$ & $1694-10896$ & $(-54)-1104$ & Fisher et al. (1982) \\
Georgia Bay (GA, USA) & 118.8 & 1384 & 536 & Hopkinson (1987) \\
Potomac Estuary (MD, USA) & 67 & $1000-21000$ & $100-2000$ & Callender \& Hammond (1982) \\
Cádiz Bay (Spain) & $69.1-235.8$ & $6200-36600$ & $500-9100$ & Forja et al. (1994) \\
Skagerrak (North Sea) & - & $(-61)-45$ & $(-14)-101$ & Hall et al. (1996) \\
Mobile Bay (AL, USA) & $3.1-39$ & $(-528)-4344$ & $(-48)-480$ & Cowan et al. (1996) \\
Chesapeake Bay (VA, MD, USA) & $9.4-23.6$ & $360-1944$ & $(-36)-312$ & Cowan \& Boynton (1995) \\
Alfacs Bay (Spain) & $1.51-57.1$ & $0-3840$ & - & Vidal et al. (1992) \\
Palmones Estuary (Spain) & $2.85-6.89$ & - & $21.6-11.4$ & Clavero et al. (1994) \\
Northwestern Black Sea & $0-33$ & $2600-4400$ & 500 & Friedl et al. (1998) \\
Palmones Estuary (Spain) & $62.5-87.4$ & $3189-9581$ & $266-1597$ & Present study \\
\end{tabular}
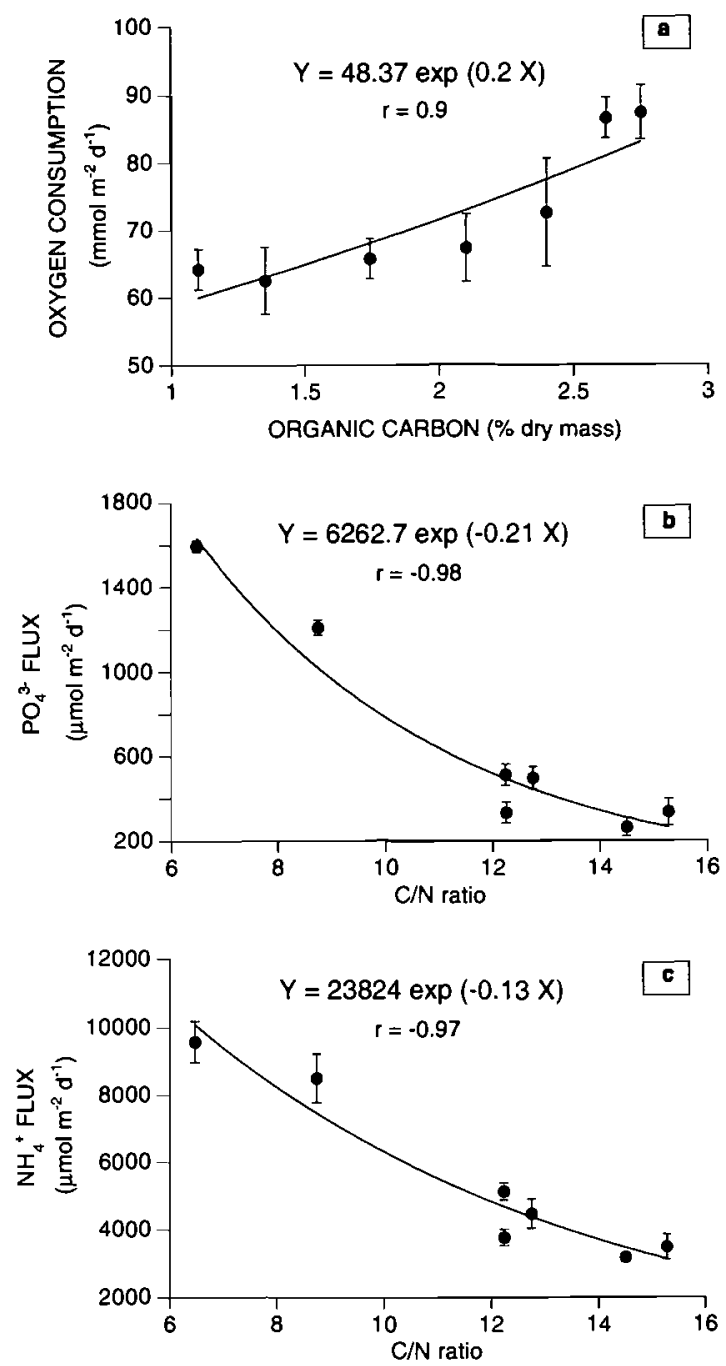

Fig. 6. Variation (mean \pm standard deviations) of (a) oxygen consumption with organic carbon, and (b) phosphate and (c) ammonium fluxes with carbon:nitrogen ratio. Values of organic carbon, and $\mathrm{C}: \mathrm{N}$ atomic ratio are for the upper $2 \mathrm{~cm}$ of sediment, from in situ benthic flux chambers reported previously (Grundmanis \& Murray 1982, Martens \& Klump 1984, Klump \& Martens 1987). Organic matter degradation follows first-order kinetics with respect to organic matter content. We observed a negative correlation between the fluxes of phosphate $(\mathrm{r}=-0.98, \alpha=0.001)$ and ammonium ( $\mathrm{r}=-0.97, \alpha=$ 0.001 ) and the $C: N$ ratio in organic matter from the upper $2 \mathrm{~cm}$ of sediment (Fig. 6b,c), suggesting the dependence of phosphate and ammonium regeneration on the quality of organic matter in the sediment (Boynton \& Kemp 1985).

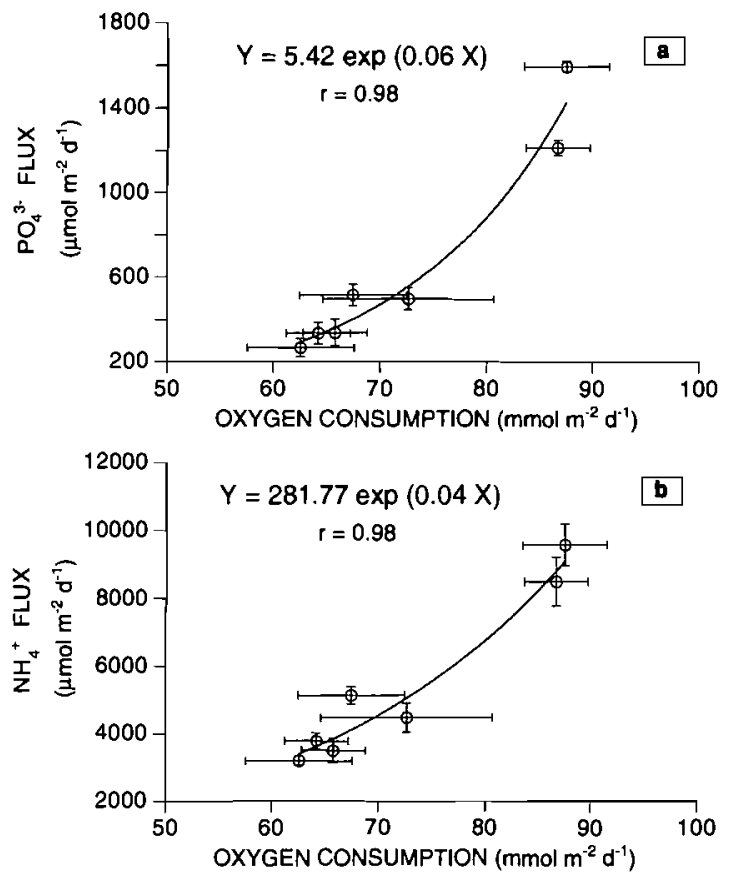

Fig. 7. Variation (mean \pm standard deviations) of (a) phosphate and (b) ammonium fluxes with oxygen consumption, from in situ benthic flux chambers 
According to the stoichiometric ratio proposed by Redfield et al. (1963), the aerobic decomposition of organic matter from phytoplankton should yield dissolved constituents in the following molar ratios $\mathrm{N}\left(\mathrm{NH}_{4}{ }^{+}\right): \mathrm{P}\left(\mathrm{PO}_{4}{ }^{3-}\right)=16$ and $\mathrm{O}: \mathrm{N}\left(\mathrm{NH}_{4}{ }^{+}\right)=13.25$. Significant correlations were obtained $(\mathrm{r}=0.98, \alpha=0.001$ for phosphate and ammonium) for oxygen consumption versus $\mathrm{PO}_{4}{ }^{3-}$ and $\mathrm{NH}_{4}{ }^{+}$regeneration (Fig. 7). The yearly averages for these ratios were $\mathrm{NH}_{4}{ }^{+}: \mathrm{PO}_{4}{ }^{3-}=9.43$ and $\mathrm{O}: \mathrm{NH}_{4}{ }^{+}=14.71$ (Table 3). The values of $\mathrm{O}: \mathrm{NH}_{4}{ }^{+}$ are close to the Redfield ratio, but $\mathrm{NH}_{4}{ }^{+}: \mathrm{PO}_{4}{ }^{3-}$ values are significantly lower. Further, $\mathrm{NH}_{4}{ }^{+}: \mathrm{PO}_{4}{ }^{3-}$ and $\mathrm{O}: \mathrm{NH}_{4}{ }^{+}$ratios decreased dramatically in the summer (mean $\mathrm{NH}_{4}{ }^{+}: \mathrm{PO}_{4}{ }^{3-}=6.5$; O: $\mathrm{NH}_{4}{ }^{+}=9.5$; Table 3), suggesting anaerobic decomposition of organic matter (Forja et al. 1994, Cowan et al. 1996). The low values of $\mathrm{NH}_{4}{ }^{+}: \mathrm{PO}_{4}{ }^{3-}$ may also be explained by preferential phosphate release during the initial stages of decomposition of organic matter or by preferential accumulation of nitrogen in sediments (Hopkinson 1987). Moreover the large phosphate fluxes may represent anoxic degradation of phosphorus-containing iron oxyhydroxides which form during winter and spring months (Krom \& Berner 1981) or by means of adsorption-desorption mechanisms (Froelich 1988, Fox et al. 1989), influenced by changes in salinity (Clavero et al. 1993).

(4) The mean $\mathrm{NH}_{4}{ }^{+}: \mathrm{PO}_{4}{ }^{3-}$ obtained in the present study is similar to values obtained by other authors (Nixon et al. 1980, Klump \& Martens 1981, Callender \& Hammond 1982, Friedl et al. 1998). The relative importance of benthic recycling of nutrients can also be stressed by calculating turnover times, an idealized parameter that represents the time necessary to replace the standing stock by benthic supply only, disregarding external sources such as river, atmospheric or lateral advective inputs. Concentrations of dissolved nutrients integrated over the water depth and divided by the benthic flux input yield the turnover time. We tested this parameter for phosphate, because we have historical data for this nutrient only. We used the mean concentrations of phosphate in the open water column (3.56 $\left.\mu \mathrm{mol} \mathrm{l}^{-1}\right)$ integrated over the mean depth $(1.5 \mathrm{~m})$ and divided by the mean in situ phosphate fluxes $\left(680 \mu \mathrm{mol} \mathrm{m}^{-2} \mathrm{~d}^{-1}\right)$. Thus turnover time calculated for 1996 to 1997 was 8 d, whereas turnover time calculated in Palmones for 1987 to 1992 was 11 d (Clavero 1992). This increase in phosphate turnover time in the Palmones River Estuary is in agreement with the progressive eutrophication of the system (Carreira et al. 1995, Niell et al. 1996, Clavero et al. 1997a, 1999).

Acknowledgements. This work was supported by Grant AMB96-0782 of The Spanish Commission of Interministery Science and Technology. Special thanks to K. C. Ruttenberg for her interest and for her helpful and insightful comments throughout this work.

\section{LITERATURE CITED}

Aller RC (1980) Diagenetic processes near the sedimentwater interface of Long Island Sound. I. Decomposition and nutrient element geochemistry $(S, N, P)$. Adv Geophys 22:237-250

Aller RC, Benninger LK (1981) Spatial and temporal pattern of dissolved ammonium, manganese and silica fluxes from the bottom sediments of Long Island Sound, USA. J Mar Res 39:295-314

Aller RC, Mackin JE, Ulman WJ, Chen-You W, Shing-Min T, Jian-Cai J, Yong-Nian S, Tia-Zhen H (1985) Early chemical diagenesis, sediment-water solute exchange, and storage of reactive organic matter near the mouth of the Changjians East Chine. Contin Shelf Res 4:227-251

Avilés A (1998) Observaciones sobre el contenido de fósforo en el Río Palmones y las repercusiones en su estuario. MSc thesis, University of Cádiz

Balzer W, Grasshof K, Dieckman P, Haardt H, Peterson U (1983) Redox turnover rate the sediment water interface studied in large bell jar system. Oceanol Acta 6:337-344

Berner RA (1980) Early diagenesis. Princeton Press, Princeton, NJ

Blackburn TH, Henriksen K (1983) Nitrogen cycling in different types of sediments from Danish waters. Limnol Oceanogr 28:477-493

Boynton WR, Kemp WM (1985) Nutrient regeneration and oxygen consumption by sediments along an estuarine salinity gradient. Mar Ecol Prog Ser 23:45-55

Boynton WR, Kemp WM, Osbourne CG (1980) Nutrient fluxes across the sediment-water interface in the turbid zone of a coastal plain estuary. In: Kennedy US (ed) Estuarine perspectives. Academic Press, New York, p 93-109

Callender E, Hammond DE (1982) Nutrient exchange across the sediment-water interface in the Potomac River estuary. Estuar Coast Shelf Sci 15:395-413

Carreira JA, Clavero V, Gálvez JA, Guevara JM, Hernández I, Lucena J, Niell FX, Peralta G, Pérez-Llorens JL, Vergara JJ (1995) Eutrophication progresses in the estuaries site at the end of small catchment areas. In: Kamermens P, Nienhuis PH (eds) Eutrophication and macrophytes. Netherlands Institute of Ecology, Amsterdam

Clavero V (1992) Estudio experimental y modelo de intercambio de fosfato en la interfase sedimento-agua en el Estuario del Río Palmones (Algeciras, Cádiz). PhD dissertation, University of Málaga

Clavero V, Niell FX, Fernández JA (1991) Effects of Nereis diversicolor O.F. Müller abundance on the dissolved phosphate exchange between sediment and overlying water in Palmones River Estuary (southern Spain). Estuar Coast Shelf Sci 33(2):193-202

Clavero V, Niell FX, Fernández JA (1992) Bioturbation by Nereis sp. and its effects on the phosphate flux across the sediment water interface in Palmones River Estuary (southern Spain). Hydrobiologia 235:387-392

Clavero V, García CM, Fernández JA, Niell FX (1993) Adsorption-desorption of phosphate and its availability in the sediment of a saline lake (Fuente de Piedra, southern Spain). Int J Salt Lake Res 2(2):153-163

Clavero V, Niell FX, Fernández JA (1994) An experimental approach to quantify the influence of Nereis diversicolor in the interchange of phosphate between sediment and water. J Exp Mar Biol Ecol 176:257-267

Clavero V, Fernández JA, Niell FX (1997a) The influence of tidal regime on phosphate accumulation in a shallow small estuary (Palmones River, southern Spain). Sci Mar 6(1): $37-43$ 
Clavero V, García-Sánchez MJ, Fernández JA, Niell FX (1997b) Influence of sulfate enrichment on the carbon dioxide and phosphate fluxes across the sediment-water interface. Hydrobiologia 345:59-65

Clavero V, Izquierdo JJ, Palomo L, Fernández JA, Niell FX (1999) Water management and climate changes increase the phosphorus accumulation in the small shallow estuary of Palmones River (southern Spain). Sci Total Environ 228:193-202

Cowan JLW, Boynton WR (1996) Sediment-water oxygen and nutrient exchanges along the longitudinal axis of Chesapeake Bay: seasonal patterns, controlling factors and ecological significances. Estuaries 19(3):562-580

Cowan JLW, Pennock JR, Boynton WR (1996) Seasonal and interannual patterns of sediment-water nutrient and oxygen fluxes in Mobile Bay, Alabama (USA): regulating factors and ecological significance. Mar Ecol Prog Ser 141: $229-245$

Elderfield HRJ, Luedtke N, McCaffrey RJ, Bender M (1981) Benthic fluxes in Narragansett Bay. Am J Sci 281:768-787

Estacio FJ, García-Adiego EM, Carballo JL, Sánchez-Moyano JE, lzquierdo JJ, Garcia-Gómez JC (1999) Interpreting temporal disturbances in an estuarine benthic community under combined anthropogenic and climatic effects. J Coast Res 15(1):155-167

Fernández JA, Niell FX, Lucena J (1985) A rapid and sensitive automated determination of phosphate in natural waters. Limnol Oceanogr 30(1):227-230

Fisher TR, Carlson P, Barber R (1982) Sediment nutrient regeneration in three North Carolina estuaries. Estuar Coast Shelf Sci 14:101-116

Forja JM, Blasco J, Gómez-Parra A (1994) Spatial and seasonal variation of in situ benthic fluxes in the Bay of Cádiz (South-West Spain). Estuar Coast Shelf Sci 39:127-141

Fox I, Malati MA, Perry R (1989) The adsorption and release of phosphate from sediments for a river receiving sewage effluent. Wat Res 23:725-732

Friedl G, Dinkel C, Wehrli B (1998) Benthic fluxes of nutrients in the northwestern Black Sea. Mar Chem 62:77-88

Froelich PN (1988) Kinetic control of dissolved phosphate in natural rivers and estuaries: a primer on the phosphate buffer mechanism. Limnol Oceanogr 33(4/2):649-668

Furrer G, vonGouten V, Zobrist J (1996) Steady-state modelling of biochemical processes in columns with aquifer material 1. Speciation and mass balances. Chem Geol 133:15-28

Grundmanis V, Murray J (1982) Aerobic respiration in pelagic marine sediments. Geochim Cosmochim Acta 46: $1101-1120$

Hall POJ, Hulth S, Hulthe G, Landen A, Tengberg A (1996) Benthic nutrient fluxes on a basin-wide scale in the Skagerrak (North-Eastern North Sea). J Sea Res 35(1-3): 123-137

Hammond DE, Fuller C, Darmon D, Hartman B, Korsec $M$, Miller LG, Rea R, Warren S, Berelson W, Hager SW (1985) Benthic fluxes in San Francisco Bay. Hydrobiologia 129: $69-90$

Hernández I, Pérez-Llorens JL, Fernández JA, Niell FX (1994) Alkaline phosphatase activity in Zostera noltii Hornem and its contribution to release of phosphate in the Palmones River Estuary. Estuar Coast Shelf Sci 39:461-476

Hernández I, Peralta G, Pérez-Llorens JL, Vergara JJ, Niell FX (1997) Biomass and dynamics of growth of Ulva species in Palmones River Estuary. J Appl Phycol 33:764-772

Hopkinson CS (1987) Nutrient regeneration in shallow-water sediments of the estuarine plume region of the nearshore Georgia Bight, USA. Mar Biol 94:127-142
Hopkinson CS, Wetzel RL (1982) In situ measurements of nutrient and oxygen fluxes in a coastal marine benthic community. Mar Ecol Prog Ser 10:29-35

Ingall $E$, Jahnke R (1997) Influence of water-column anoxia on the elemental fractionation of carbon and phosphorus during sediment diagenesis. Mar Geol 139:219-229

Izquierdo JJ (1996) Efectos de manifestaciones climáticas extremas en el ciclo del fósforo en estuarios de renovación diaria. MSc thesis, University of Málaga

Jørgensen BB, Sørensen $\mathrm{J}$ (1985) Seasonal cycles of $\mathrm{O}_{2}, \mathrm{NO}_{3}{ }^{-}$ and $\mathrm{SO}_{4}{ }^{2-}$ reduction in estuarine sediments: the significance of an $\mathrm{NO}_{3}{ }^{-}$reduction maximum in spring. Mar Ecol Prog Ser 24:65-74

Kelderman P (1984) Sediment-water exchange in Lake Grevelingen under different environmental conditions. Neth $\mathrm{J}$ Sea Res 18:286-311

Klump JV, Martens CS (1981) Biogeochemical cycling in an organic-rich coastal marine basin. II. Nutrient sedimentwater exchange processes. Geochim Cosmochim Acta 45: 101-121

Klump JV, Martens CS (1987) Biogeochemical cycling in an organic-rich coastal marine basin. V. Sedimentary nitrogen and phosphorus budgets based upon kinetic models, mass balances, and stoichiometry of nutrient regeneration. Geochim Cosmochim Acta 51:1161-1173

Krom MD, Berner RA (1980) The diffusion coefficients of sulfate, ammonium, and phosphate ions in anoxic marine sediments. Limnol Oceanogr 25:327-337

Krom MD, Berner RA (1981) The diagenesis of phosphorus in a nearshore marine sediment. Geochim Cosmochim Acta 45:207-216

Li VH, Gregory S (1974) Diffusion of ions in sea water and in deep-sea sediments. Geochim Cosmochim Acta 38: 703-714

Libes SM (1992) An introduction to marine biogeochemistry. John Wiley \& Sons, New York

Manheim FT (1970) The diffusion of ions in unconsolidated sediments. Earth Planet Sci Lett 9:307-309

Martens CS, Klump JV (1984) Biogeochemical cycling in an organic-rich coastal marine basin. IV. An organic carbon budget for sediment dominated by sulphate reduction and methanogenesis. Geochim Cosmochem Acta 48:1987-2004

Martin WR, Bender ML (1988) The variability of benthic fluxes and sedimentary rates in response to seasonally variable organic carbon rain rates in the deep sea: a modelling study. Am J Sci 288:561-574

McCaffrey RJ, Myers AC, Davye E, Morrison G, Bender M Luedtke N, Cullen D, Froelich P, Klinkhammer G (1980) The relation between pore water chemistry and benthic fluxes of nutrients and manganese in Narragansett Bay, Rhode Island. Limnol Oceanogr 25(1):31-44

Niell FX, Fernández C, Figueroa FL, Figuerias FG, Fuentes JM, Pérez-Llorens JL, García MJ, Hernández I, Fernández JA, Espejo M, Buela J, García-Jiménez MC, Clavero V, Jiménez C (1996) Spanish Atlantic coasts. In: Schramm W, Nienhuis PH (eds) Marine benthic vegetation. SpringerVerlag, Berlin, p 265-281

Nixon SW, Oviatt CA, Hale SS (1976) Nitrogen regeneration and the metabolism of coastal marine bottom communities. In: Anderson JM, MacFayden A (eds) The role of terrestrial and aquatic organisms in decomposition processes. Blackwell, Oxford, p 269-283

Nixon SW, Kelly JR, Furnas BN, Oviatt CA, Hale SS (1980) Phosphorus regeneration and the metabolism of coastal marine bottom communities. In: Tenore KB, Coull BC (eds) Marine benthic dynamics. University of South Carolina Press, Columbia, p 219-242

Pérez-Llorens JL, Niell FX (1990) Seasonal dynamics of bio- 
mass and content in the intertidal seagrass Zostera noltit from Palmones River Estuary. Aquat Bot 46:49--66

Plante $R$, Alcolado PM, Martinez-Iglesias JC, Ibarzabal D (1989) Redox potential in water and sediment of the Gulf of Batabanó. Estuar Coast Shelf Sci 28:173-184

Redfield A, Ketchum BH, Richards FA (1963) The influence of organisms on the composition of sea-water. In: Hill $\mathrm{NH}$, Goldberg ED, Iselin COD, Munk WH (eds) The sea. John Wiley \& Sons, New York, p 26-77

Revsbech NP, Sørensen J, Blackburn TH, Cohen Y (1983) Microelectrode studies of the photosynthesis and $\mathrm{O}_{2}, \mathrm{H}_{2} \mathrm{~S}$, and $\mathrm{pH}$ profiles of a microbial mat. Limnol Oceanogr 28: $1062-1074$

Seitzinger S (1987) Nitrogen biogeochemistry in an unpolluted estuary: the inportance of benthic denitrification. Mar Ecol Prog Ser 41:177-186

Slawyk G, MacIsaac JJ (1972) Comparison of two automated ammonium methods in a region of coastal upwelling. Deep-Sea Res 19:521-524

Smith KL, Lawer MB, Brown NO (1983) Sediment community oxygen consumption and nutrient exchange in the central and eastern North Pacific. Limnol Oceanogr 28(5): 882-898

Editorial responsibility: Otto Kinne (Editor),

Oldendorf/Luhe, Germany
Soetaert K, Herman PMJ, Middelburg JJ (1996) Dynamic response of deep-sea sediments to seasonal variation: a model. Lirnol Oceanogr 41:1651-1668

Soetaert K, Herman PMJ, Middelburg JJ (1998) Assessing organic matter mineralization, degradability and mixing rate in an ocean margin sediment (Northeast Atlantic) by diagenetic modeling. J Mar Res 56:519-534

Sommers LE, Nelson DW (1972) Determination of total phosphorus by a rapid perchloric acid procedure. Soil Sci Soc Am Proc 36:902-904

van Cappellen P, Gaillard JF (1996) Biogeochemical dynamics in aquatic sediments. In: Lichtner PC, Steefel C, Oelkers $\mathrm{EH}$ (eds) Reactive transport in porous media. Reviews in mineralogy, Vol 34. Mineralogical Society of America, Washington, $\mathrm{DC}$

Vidal M, Morguí JA, Latasa M, Romero J, Camp J (1992) Factors controlling spatial variability in ammonium release within an estuarine bay (Alfacs Bay, Ebro Delta, NW Mediterranean). Hydrobiologia 235:519-525

Witt $R$, Jonkers HM, van den Ende FP, Gemerden H (1989) In situ fluctuations of oxygen and sulphide in marine microbial sediment ecosystems. Neth J Sea Res 23:271-281

Submitted: March 22, 1999; Accepted: November 25, 1999 Proofs received from author(s): May 9, 2000 